\title{
Treatment of Paper and Pulp Mill Wastewater by Ozonation Combined with Electrolysis
}

\author{
Naoyuki KISHIMOTO*, Takahiro NAKAGAWA**, Hirokazu OKADA***, \\ Hiroshi MIZUTANI*** \\ *Faculty of Science and Technology, Ryukoku University, Otsu 520-2194 Japan \\ **Graduate School of Science and Technology, Ryukoku University, Otsu 520-2194 Japan \\ ***Mitsubishi Heavy Industries Environmental \& Chemical Engineering Co. Ltd., Yokohama \\ 231-8715 Japan
}

\begin{abstract}
Ozonation combined with electrolysis (ozone-electrolysis), ozonation alone and electrolysis alone were applied to the treatment of a paper and pulp mill wastewater for the decolorization and removal of chemical oxygen demand (COD). Electrolysis alone was ineffective in treating the paper and pulp mill wastewater. Both ozone-electrolysis and ozonation alone were effective in removing chromaticity, but produced white suspended solids. The production of the solid by ozone-electrolysis was smaller than by ozonation alone. The ozone-electrolysis demonstrated more rapid removal of COD and higher ozone effectivity than the ozonation alone. Furthermore, ozone-electrolysis was the most useful method to transform organic compounds into more oxygenated ones of the three.
\end{abstract}

Keywords: advanced oxidation process, COD removal, decolorization

\section{INTRODUCTION}

Paper is mainly made from wood pulp and the major compositions of wood pulp are cellulose and hemicellulose. However, woods contain lignin in addition to cellulose and hemicellulose. Accordingly, delignification is required at the pulping step. The most popular pulping method is the kraft process, in which wood chips and a mixture of sodium hydroxide and sodium sulfide are added into a digester. In the digester, delignification of wood chips progresses for $1-2$ hours at a temperature of $70{ }^{\circ} \mathrm{C}$ to cooking temperature (about $170{ }^{\circ} \mathrm{C}$ ). During this treatment, lignin is extensively degraded and degradation products are dissolved (Gierer, 1980). The finished cooked wood chips are separated from the cooked liquor and are washed with water to remove residual lignin. The brown effluent from this step contains high concentration of organic matters to be removed by wastewater treatment processes. Paper and pulp factories use about $200 \mathrm{~m}^{3}$ of water for the production of one ton of cellulose (Nakamura et al., 1997).

Paper and pulp mill wastewater is conventionally treated by a combination of sedimentation, floatation, sand filtration, coagulation, biological treatment and other processes. (Fontanier et al., 2006). In the conventional process, organic matter is effectively removed by biological processes. However, decolorization and removal of bio-refractory organic pollutants are insufficiently achieved by biological processes alone (Gökcay and Dilek, 1994; Sevimli, 2005). Ozonation can enhance the biodegradability of the bio-refractory organic matter (Bijan and Mohseni, 2004; Möbius and Helble, 2004; Medeiros et al., 2008). However, since some organic pollutants resist

Address correspondence to Naoyuki Kishimoto, Department of Environmental Solution Technology, Faculty of Science \& Technology, Ryukoku University, Email: naoyuki@rins.ryukoku.ac.jp Received December 15, 2009, Accepted March 15, 2010. 
ozonation, it is difficult to achieve complete decolorization of wastewater by ozonation (Bijan and Mohseni, 2004; Sevimli, 2005; Medeiros et al., 2008).

Advanced oxidation processes (AOPs) are processes involving the generation of hydroxyl radicals in sufficient quantity to affect water purification (Glaze et al., 1987). As the hydroxyl radical is a strong oxidant with standard potentials of $2.38 \mathrm{~V}$ in acid solution, decolorization of wastewater is enhanced by AOPs (Sevimli, 2005).

Although there are many types of AOPs such as ozone $/ \mathrm{H}_{2} \mathrm{O}_{2}$ and ozone/UV (Gottschalk et al., 2000), ozonation combined with electrolysis (ozone-electrolysis) was applied to paper and pulp mill wastewater treatment in this study, to reveal its effect on decolorization and chemical oxygen demand (COD) removal. The ozone-electrolysis is a new AOP. The advanced oxidation mechanism for ozone-electrolysis was estimated to be as follows (Kishimoto et al., 2005; Kishimoto et al., 2008):

$$
\begin{aligned}
& \mathrm{O}_{3}+\mathrm{e}^{-} \rightarrow \mathrm{O}_{3}^{-} \quad \text { at cathodes } \\
& \mathrm{O}_{3}^{-}+\mathrm{H}_{2} \mathrm{O} \rightarrow \mathrm{OH}+\mathrm{O}_{2}+\mathrm{OH}^{-}
\end{aligned}
$$

The advantages of ozone-electrolysis compared with other AOPs are (1) reagents such as hydrogen peroxide or ferrous salts are unnecessary, (2) there is less influence from chromaticity, and (3) electric power is required only for operation (Kishimoto et al., 2008).

\section{MATERIALS AND METHODS}

\section{Paper and Pulp Mill Wastewater}

Washings from cooked pulp of an actual paper and pulp factory were used as wastewater in this study. The wastewater was pre-filtrated with a glass filter with 2.7 $\mu \mathrm{m}$ pores $(\mathrm{GF} / \mathrm{D}$, Whatman, $\mathrm{UK})$ to simulate the sedimentation process. Table 1 summarizes the water quality of the filtrated wastewater.

\begin{tabular}{|c|c|c|c|}
\hline Item & Value & Item & Value \\
\hline $\mathrm{pH}$ & 8.3 & $\mathrm{Ca}^{2+}$ & $6.1 \mathrm{mg} / \mathrm{L}$ \\
\hline Electrical conductivity (EC) & $1.43 \mathrm{mS} / \mathrm{cm}$ & $\mathrm{Mg}^{2+}$ & $67 \mathrm{mg} / \mathrm{L}$ \\
\hline Suspended solid (SS) & $15.2 \mathrm{mg} / \mathrm{L}$ & $\mathrm{Na}^{+}$ & $364 \mathrm{mg} / \mathrm{L}$ \\
\hline Chemical oxygen demand (COD) & $1,382 \mathrm{mg} / \mathrm{L}$ & $\mathrm{K}^{+}$ & $15.4 \mathrm{mg} / \mathrm{L}$ \\
\hline Total organic carbon (TOC) & $400 \mathrm{mg} / \mathrm{L}$ & $\mathrm{Cl}^{-}$ & $19.4 \mathrm{mg} / \mathrm{L}$ \\
\hline Total nitrogen $(\mathrm{TN})$ & $13.8 \mathrm{mgN} / \mathrm{L}$ & $\mathrm{SO}_{4}{ }^{2-}$ & $106 \mathrm{mg} / \mathrm{L}$ \\
\hline Ammonia nitrogen $\left(\mathrm{NH}_{4}-\mathrm{N}\right)$ & $2.2 \mathrm{mgN} / \mathrm{L}$ & & \\
\hline Nitrite nitrogen $\left(\mathrm{NO}_{2}-\mathrm{N}\right)$ & N.D. & & \\
\hline Nitrate nitrogen $\left(\mathrm{NO}_{3}-\mathrm{N}\right)$ & $0.1 \mathrm{mgN} / \mathrm{L}$ & & \\
\hline Total phosphorus (TP) & $3.2 \mathrm{mgP} / \mathrm{L}$ & & \\
\hline Orthophosphate $\left(\mathrm{PO}_{4}-\mathrm{P}\right)$ & $1.1 \mathrm{mgP} / \mathrm{L}$ & & \\
\hline
\end{tabular}

Table 1 - Water quality of filtrated paper and pulp mill wastewater.

N.D.; not detected.

\section{Experimental Equipment}

Fig. 1 shows the experimental setup. The reactor was composed of a bubble column (for 
the contact of ozone gas with wastewater) and a two-compartment electrolytic flow cell. The bubble column was a glass cylinder with a water jacket. The inner diameter of the column was $4 \mathrm{~cm}$ and the effective water depth was $99 \mathrm{~cm}$. Ozone gas was generated from oxygen gas using a silent discharge ozone generator (ED-OG-R3Lt, Ecodesign, Japan) and was injected into the bubble column through a glass diffuser installed at the bottom of it. Ozone concentration in the inlet and outlet gases was continuously monitored using two ozone gas monitors (EG-600, Ebarajitsugyo, Japan). The outlet gas was dried with a gas dryer (DH106-1, Komatsu Electronics, Japan) before monitoring the ozone concentration. The gas flow rate was regulated with a flow controller (CMQ9200, Yamatake, Japan). The structure of the electrolytic cell was the same as previously reported (Kishimoto et al., 2008) except that there was no gas diffuser in this study. The anode was titanium coated with platinum and the cathode was titanium. The effective electrode area was $17.9 \mathrm{~cm}^{2}$ for both electrodes. A DC power supply (AD-8735, A\&D, Japan) was connected to each electrode. The electrolytic cell was divided into an anodic compartment and a cathodic compartment by a cation-exchange membrane (Nafion N-117, DuPont, USA) as solid electrolyte. The volume of each compartment was $31 \mathrm{~cm}^{3}$. Wastewater was circulated with a roller pump (RP-1000, EYELA, Japan) through the bubble column and the cathodic compartment via the anodic compartment. The circulation rate was set at $180 \mathrm{~mL} / \mathrm{min}$.

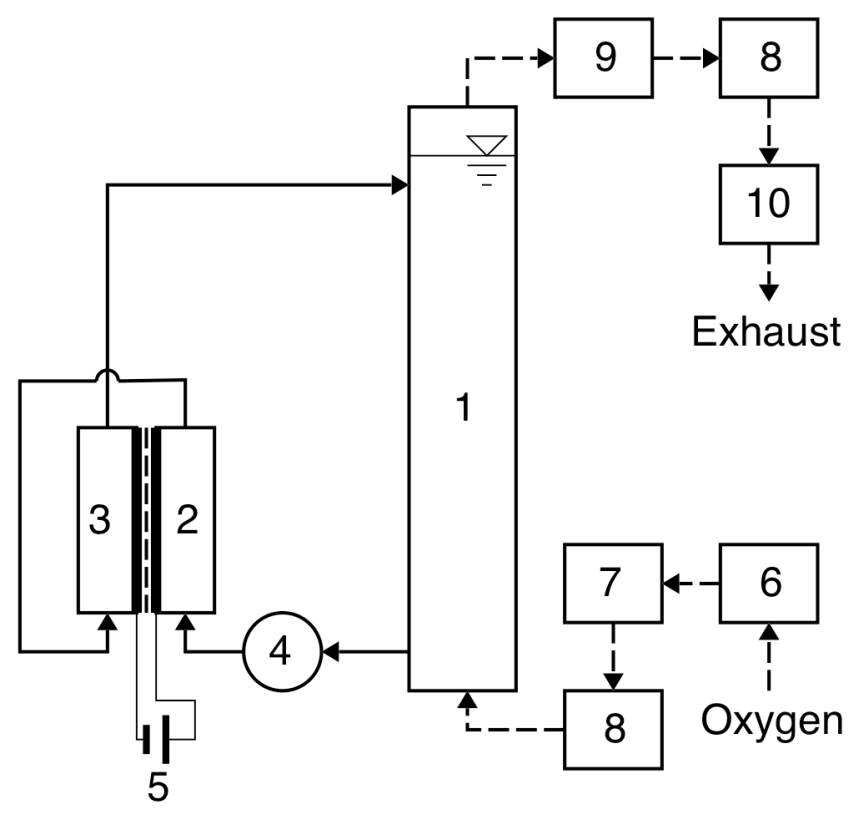

Fig. 1 - Experimental set up.

1: Bubble column, 2: Anodic compartment, 3: Cathodic compartment, 4: Roller pump, 5: DC power supply, 6: Gas flow controller, 7: Ozone generator, 8: Ozone monitor, 9: Gas dryer, 10: Ozone decomposer

\section{Experimental Procedure}

Table 2 summarizes the experimental conditions set in the study. Prior to the experiment, $1,450 \mathrm{~mL}$ of wastewater was poured into the reactor and was circulated for $10 \mathrm{~min}$ at a flow rate of $180 \mathrm{~mL} / \mathrm{min}$ with oxygen aeration. Then, the ozone generator and the $\mathrm{DC}$ 
power supply were switched on. Ozone gas flow rate was set at $100 \mathrm{~mL} / \mathrm{min}$ and ozone gas concentration was recorded every 30 seconds with a data logger (TEU-10, Espec, Japan). Water temperature in the reactor was regulated at $20 \pm 1{ }^{\circ} \mathrm{C}$ by circulating water at $20{ }^{\circ} \mathrm{C}$ through the water jacket.

Table 2 - Experimental conditions

\begin{tabular}{lllcc}
\hline Treatment type & Bubbling gas & $\begin{array}{l}\text { Ozone gas } \\
\text { conc. }\end{array}$ & $\begin{array}{l}\text { Electrolytic } \\
\text { current }\end{array}$ & $\begin{array}{l}\text { Voltage } \\
\text { observed }\end{array}$ \\
\hline Ozonation & Ozonized oxygen & $57.8 \mathrm{mgO}_{3} / \mathrm{L}$ & - & - \\
Electrolysis & Oxygen & - & $1.44 \mathrm{~A}$ & $3.9 \sim 4.0 \mathrm{~V}$ \\
Ozone-electrolysis & Ozonized oxygen & $58.9 \mathrm{mgO}_{3} / \mathrm{L}$ & $1.44 \mathrm{~A}$ & $3.9 \sim 4.0 \mathrm{~V}$ \\
\hline
\end{tabular}

Ozone dose, which is defined by the cumulative amount of ozone absorbed by one liter of wastewater, was evaluated by an integration of the difference in the ozone gas concentrations at the inlet and outlet openings multiplied by the gas flow rate and divided by the volume of the wastewater. The effluent from the bubble column was periodically sampled for chemical analysis. COD was measured by closed reflux colorimetric method (Standard Methods, 1998). Anions and cations were analyzed by ion chromatography with a suppressor (DX-500, Dionex, Sunnyvale). Total nitrogen (TN) was measured by persulfate method (Standard Methods, 1998) followed by brucine spectrophotometric method (Japanese Industrial Standards Committee, 1998). Total phosphorus (TP) analysis was carried out in accordance with JIS K 0102 (Japanese Industrial Standards Committee, 1998). The $\mathrm{pH}$ value and electrical conductivity (EC) were checked with a $\mathrm{pH}$ meter (B-212, Horiba, Japan) and an EC meter (B-173, Horiba, Japan), respectively. Total organic carbon (TOC) was determined with a TOC analyzer (TOC-V $\mathrm{V}_{\mathrm{CSN}}$, Shimadzu, Japan). Suspended solids (SS) analysis was done in accordance with JIS K 0102 (Japanese Industrial Standards Committee, 1998) except when glass fiber filter with $0.7 \mu \mathrm{m}$ pores (GF/F, Whatman, UK) was used. Carbon and nitrogen contents in solid were determined with an $\mathrm{NCH}$ analyzer (NCH-22F, Sumika Chemical Analysis Service, Japan). Absorbance spectrum was measured with a spectrophotometer (UV-2550, Shimadzu, Japan).

\section{RESULTS AND DISCUSSION Ozone Consumption}

Fig. 2 shows time-course changes of the ozone gas concentration (inlet and outlet), and ozone dose. The ozone injected into the reactor was completely consumed at the beginning (Fig. 2(a)). However, ozone was detected in the outlet gas after one hour from the beginning of the experiment. The slopes of the graphs in Fig. 2(b) were inflected at around one hour of treatment. Although the slopes for both ozonation alone and ozone-electrolysis were almost the same before the inflection point, the slope for ozonation alone was smaller than that for ozone-electrolysis after the inflection point. Thus, Fig. 2 indicates that the reactions in the reactor before and after the inflection point are different.

The depletion of ozone in the outlet gas implies that the ozone reactive substances completely consumed the ozone injected. The decline in the ozone reactive substances decreased the ozone absorption rate in the reactor and resulted in the smaller slope of 
the graph in Fig. 2(b) after one hour. The generation of hydroxyl radicals in ozone-electrolysis requires dissolved ozone. Accordingly, the generation of hydroxyl radicals through equations [1] and [2] did not happen in the reactor before one hour of treatment. Larger slope for ozone-electrolysis compared to ozonation was caused by electrolysis of ozone in the reactor. Therefore, hydroxyl radicals were thought to be effectively produced in ozone-electrolysis after the inflection point in Fig. 2(b).
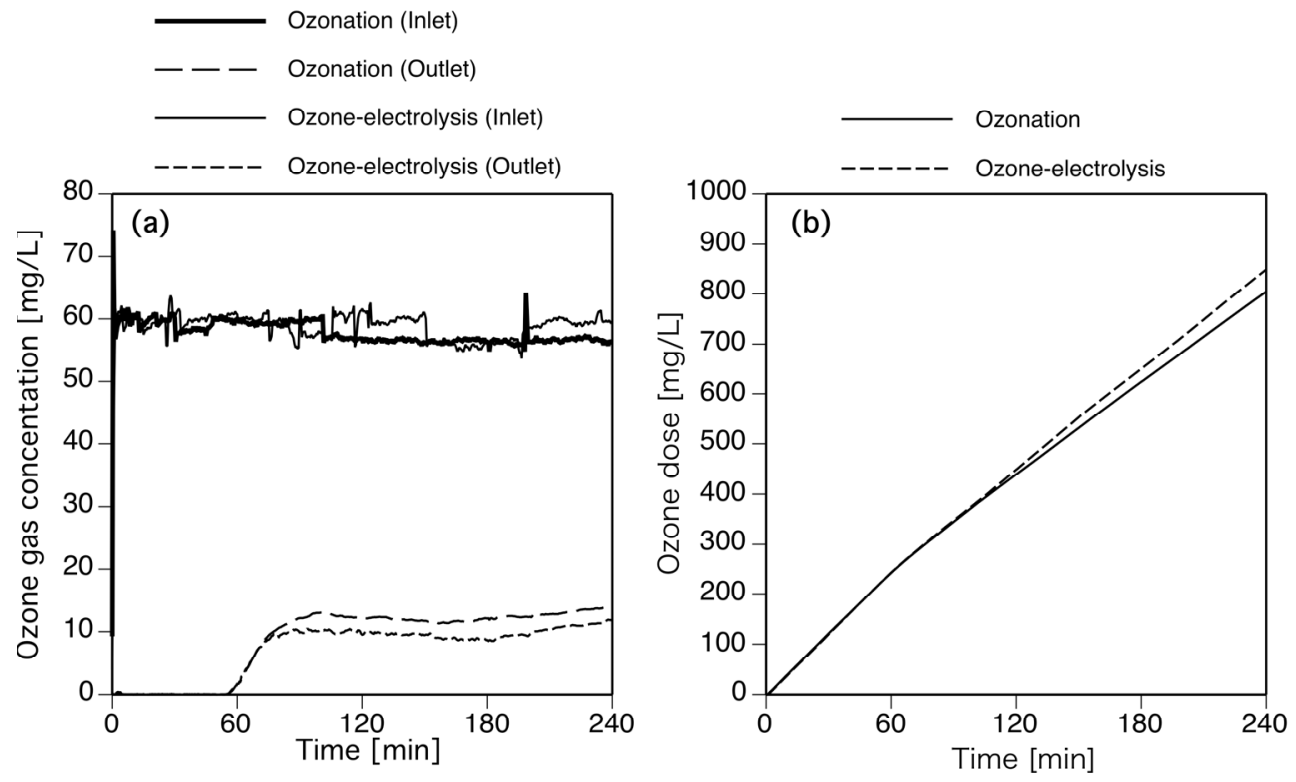

Fig. 2 - Time course of changes in inlet ozone gas concentration, outlet ozone gas concentration, and ozone dose in ozonation alone and ozone-electrolysis.

\section{Decolorization Effect}

Picture 1 shows the time course of changes in appearance of wastewater by ozonation, by electrolysis and by ozone-electrolysis. The paper and pulp mill wastewater was brownish at the beginning and electrolysis had no effect on decolorization as shown in Picture 1. Although the brownish color disappeared by ozonation or ozone-electrolysis, white haze began to be observed with the passage of time. Fig. 3 shows the time course of changes in absorbance spectra in ozonation and in ozone-electrolysis. The absorbance at longer wavelength increased with the passage of time due to the accumulation of white SS. The absorbance at $400 \mathrm{~nm}$ before and after filtration of samples with $0.45 \mu \mathrm{m}$ membrane was summarized in Fig. 4. The absorbance of filtrated samples in ozonation and ozone-electrolysis decreased steadily with the passage of time. The decreasing rate of the absorbance in ozone-electrolysis was slightly higher than that in ozonation, but the difference was quite small. Thus, ozonation and ozone-electrolysis achieved almost complete decolorization at a treatment time of 2.5 hours, which required an ozone dose of about $550 \mathrm{mgO}_{3} / \mathrm{L}$. However, the absorbance without filtration increased again after two hours of treatment by ozonation and ozone-electrolysis. Furthermore, the increase in the absorbance in ozonation was larger than that in ozone-electrolysis. This means that larger amount of white SS was produced by ozonation than by ozone-electrolysis. 


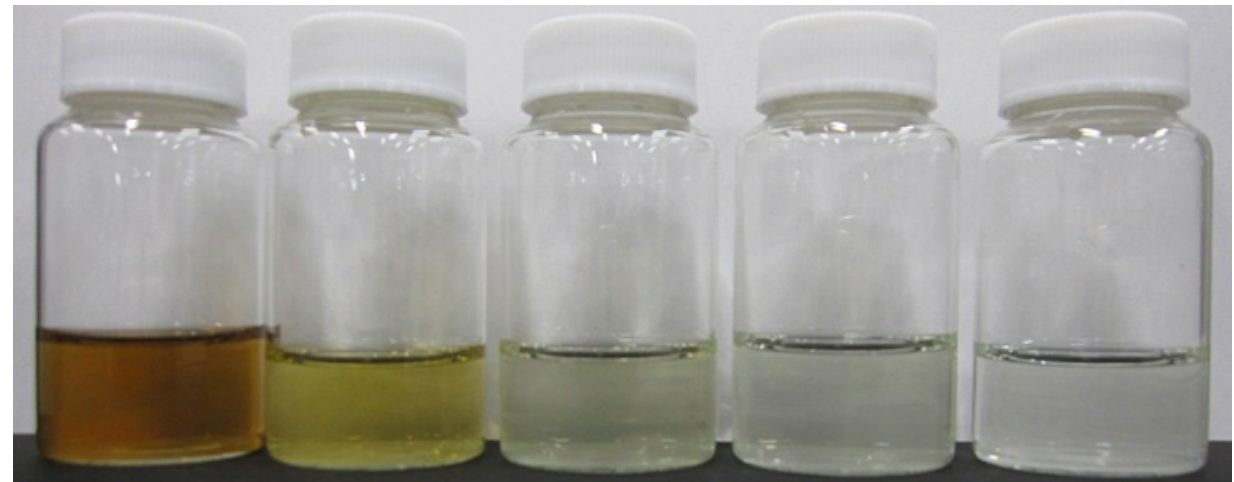

(a) Ozonation (Treatment time: $0 \mathrm{hr}, 1 \mathrm{hr}, 2 \mathrm{hr}, 3 \mathrm{hr}, 4 \mathrm{hr}$ from the left bottle)

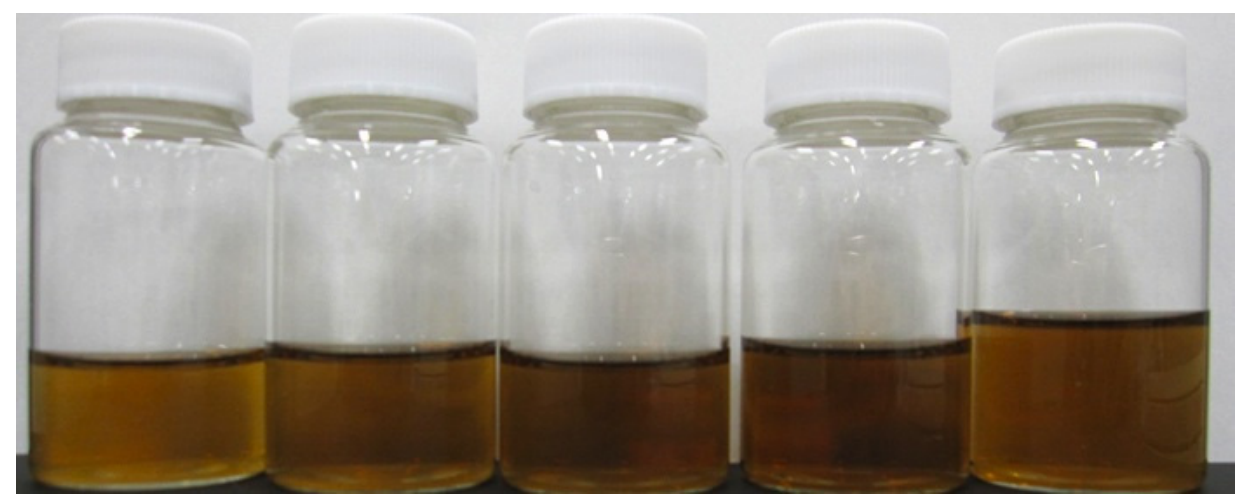

(b) Electrolysis (Treatment time: $0 \mathrm{hr}, 1 \mathrm{hr}, 2 \mathrm{hr}, 3 \mathrm{hr}, 4 \mathrm{hr}$ from the left bottle)

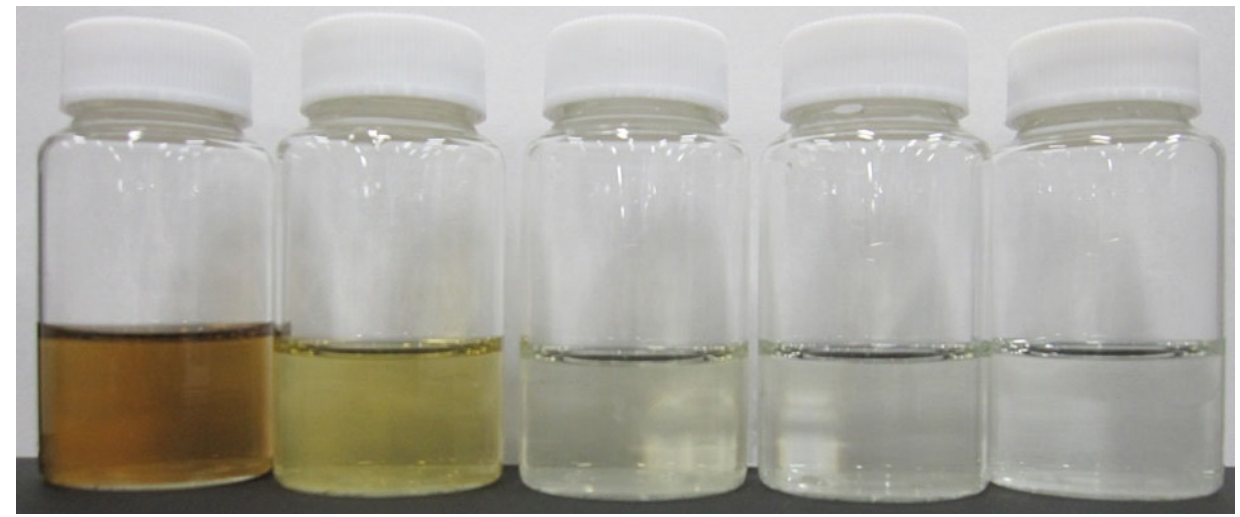

(c) Ozone-electrolysis (Treatment time: $0 \mathrm{hr}, 1 \mathrm{hr}, 2 \mathrm{hr}, 3 \mathrm{hr}, 4 \mathrm{hr}$ from the left bottle) Picture 1 - Photographs of wastewater treated by ozonation, electrolysis and ozone-electrolysis.

Carbon and nitrogen contents in white SS are summarized in Fig. 5. The solids contained $13 \%$ of carbon, $0.2 \%$ of nitrogen and $38 \%$ of ignition residue. Fontanier et al., (2006) observed a similar increase in white SS in the ozonation of a paper and pulp mill wastewater. They inferred that the white SS were magnesium and calcium complexes of carboxylated ozonation products. Changes in the amount of calcium and magnesium ions removed during treatment in this study are shown in Fig. 6. The Fig. 6 clearly shows that calcium and magnesium ions were removed by ozonation and ozone-electrolysis and the amount of magnesium ion removed by ozonation was larger than that by ozone-electrolysis. Therefore, the white SS might be partially constituted by the complexes of magnesium and carboxylated products as Fontanier et al., (2006) 
pointed out. Since carboxyl compounds are one of the major by-products of ozonation (Glaze, 1986) and hydroxyl radicals can decompose them, the accumulation of carboxylated products might be enhanced by ozonation alone. Thus, the combination of electrolysis and ozonation contributed to the decrease in the production of white SS.
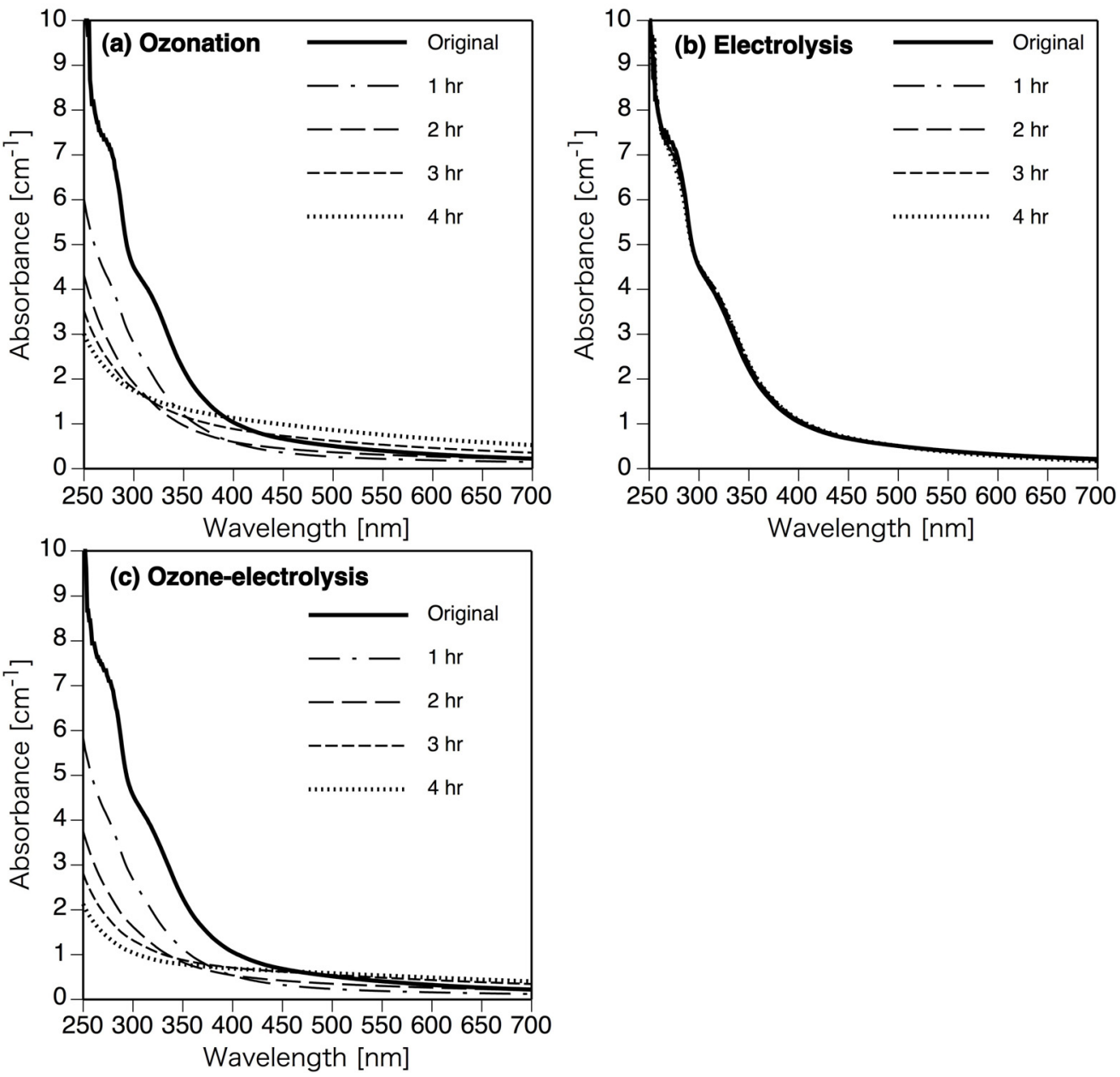

Fig. 3 - Changes in the absorbance spectra during each treatment.

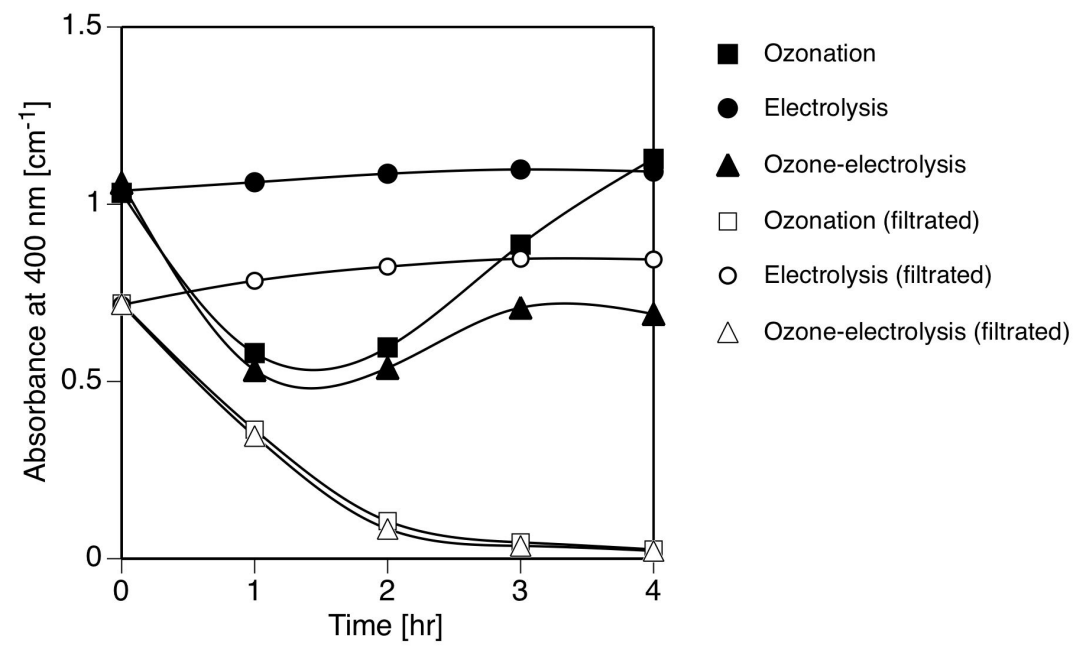

Fig. 4 - Changes in the absorbance at $400 \mathrm{~nm}$ during each treatment. 


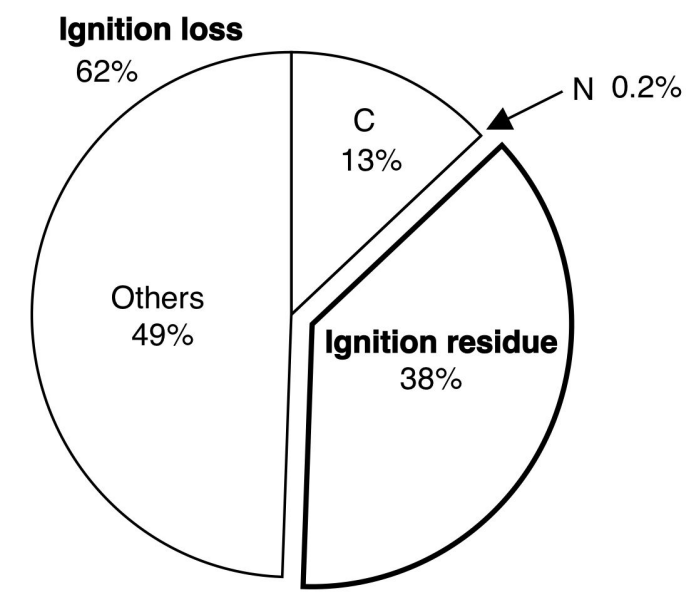

Fig. 5 - Contents of white suspended solid (weight \%).
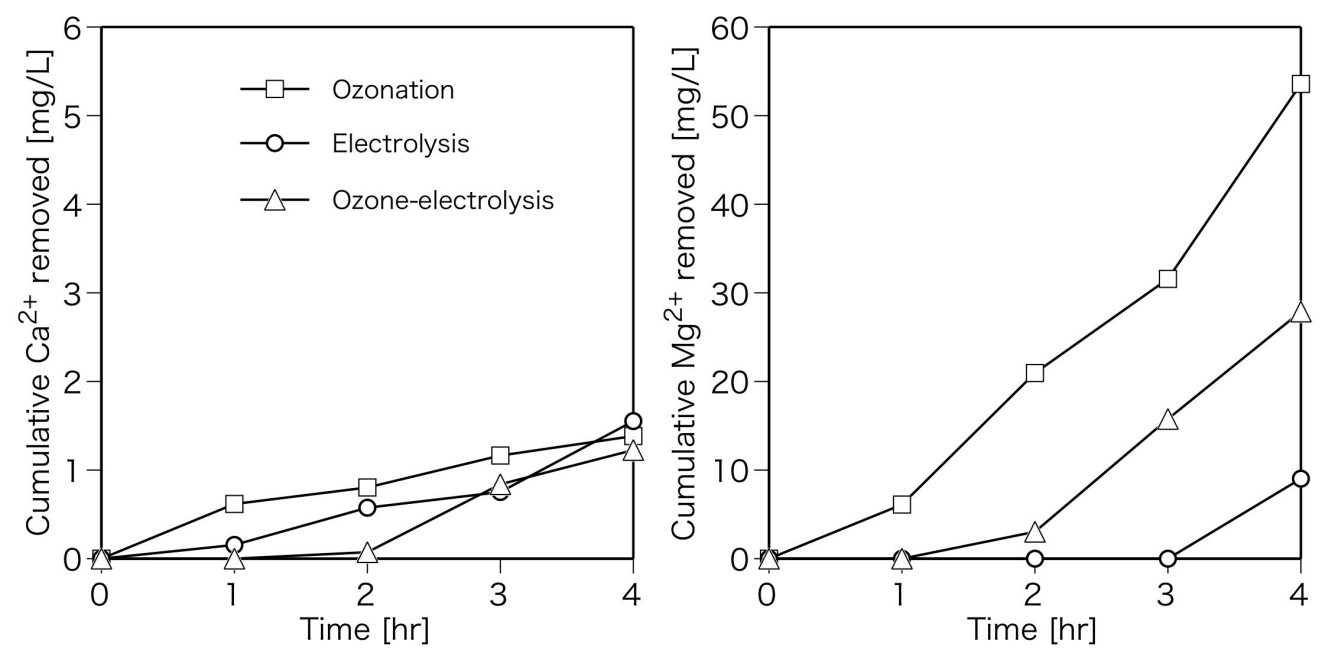

Fig. 6 - Changes in the cumulative amount of $\mathrm{Ca}^{2+}$ and $\mathrm{Mg}^{2+}$ removed during each treatment.

\section{COD Removal}

Fig. 7 shows the changes in dissolved COD during each treatment. Electrolysis was not effective in removing COD from the paper and pulp mill wastewater and ozone-electrolysis decreased COD more rapidly than ozonation. The relationship between ozone dose and cumulative COD removed is shown in Fig. 8. Since ozone effectivity (OE) is defined by the ratio of the COD removed per ozone dose, the OE in ozonation becomes lower than in ozone-electrolysis after one hour of treatment. As mentioned before, the generation of hydroxyl radicals was expected in ozone-electrolysis after one hour of treatment. Accordingly, hydroxyl radicals generated by ozone-electrolysis were inferred to contribute to the enhancement of $\mathrm{OE}$. 


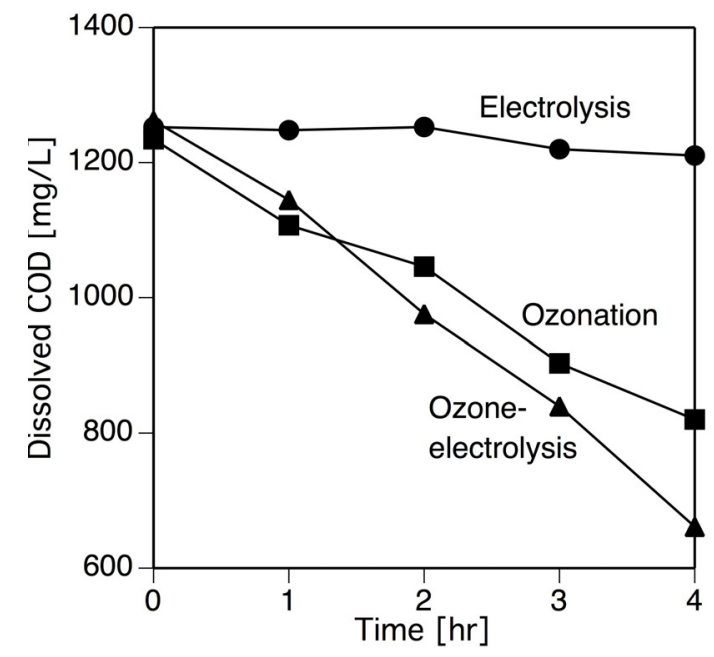

Fig. 7 - Changes in the concentration of dissolved COD during each treatment.

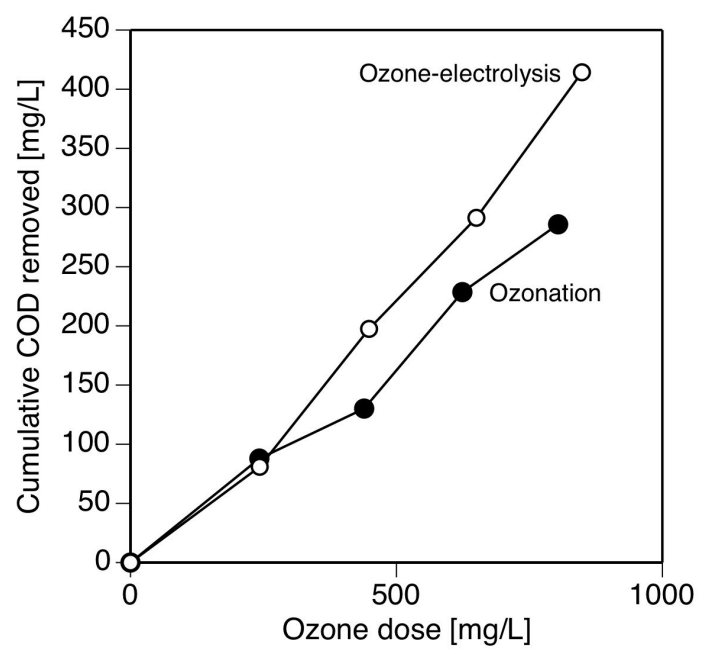

Fig. 8 - Relationship between ozone dose and cumulative COD removed.

Fig. 9 shows the changes in the ratios of COD to TOC during each treatment. Although both ozonation and ozone-electrolysis succeeded in decreasing the ratio, the decreasing rate by ozone-electrolysis was much higher than by ozonation alone after one hour of treatment. Thus, ozone-electrolysis enhanced the partial oxidation of organic matter, namely transformation of organic compounds to more oxygenated ones, due to the high oxidation-reduction potential of hydroxyl radical. Alvares et al., (2001) reviewed researches about partial oxidation of recalcitrant organic compounds by ozone and concluded that the partial oxidation contributed to the enhancement of biodegradability of the compounds. Bijan and Mohseni (2005) also reported that the smaller organic molecules were more biodegradable than the larger ones in pulp mill wastewater. They demonstrated that the partial oxidation of the pulp mill wastewater by ozone transformed the large organic molecules into the smaller ones and enhanced the biodegradability of the wastewater. Furthermore, they observed that the ozonation of the pulp mill wastewater at $\mathrm{pH} 11$ could effectively increase the biochemical oxygen demand (BOD) at the ozone dose ranging from 120 to $800 \mathrm{mg}-\mathrm{O}_{3} / \mathrm{L}-$ wastewater, whereas the ozonation at $\mathrm{pH} 4.5$ was less effective in the augmentation of BOD. As the 
ozonation in alkaline $\mathrm{pH}$ is known to generate sufficient quantity of hydroxyl radicals via the ozonide ion pathway (Tomiyasu et al., 1985), their result implies that the advanced oxidation of paper and pulp mill wastewater is also effective in enhancing the biodegradability. Thus, although we did not measure the BOD before and after treatment in this study, the ozone-electrolysis followed by a biological process was inferred to be effective in treating the paper and pulp mill wastewater.

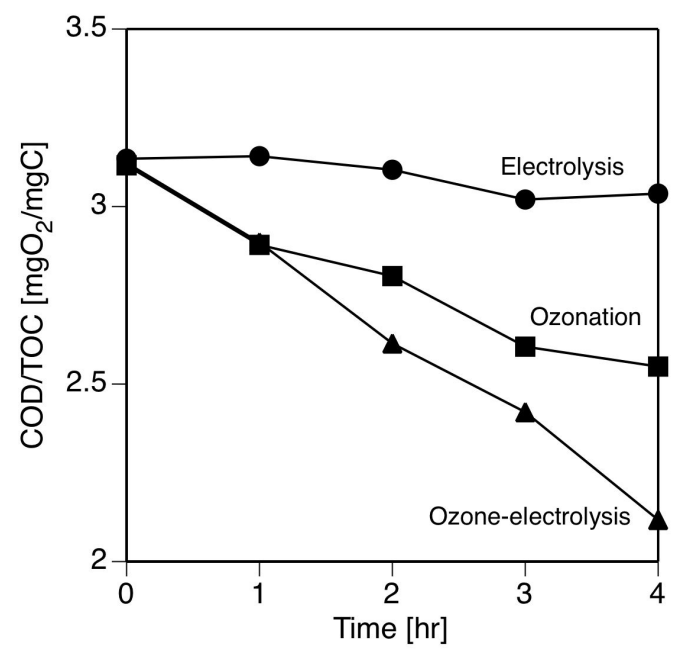

Fig. 9 - Changes in the ratio of COD to TOC during each treatment.

\section{CONCLUSIONS}

Ozonation combined with electrolysis (ozone-electrolysis) was applied to the treatment of a paper and pulp mill wastewater. The treatment performance was compared with that of ozonation alone and electrolysis alone. The obtained results are summarized as follows:

(1) Electrolysis was ineffective in both chromaticity and COD removal from the wastewater.

(2) Both ozone-electrolysis and ozonation were effective in removing chromaticity from the wastewater. Almost complete decolorization was achieved by the ozone dose of about $550 \mathrm{mgO}_{3} / \mathrm{L}$. However, white $\mathrm{SS}$ were produced during treatment. Ozone-electrolysis was able to reduce the production of the white SS in comparison with ozonation alone.

(3) The COD removal rate and the ozone effectivity in ozone-electrolysis were higher than those of ozonation alone. Hydroxyl radicals generated by ozone-electrolysis was thought to contribute to the enhancement of treatment performance. Ozone-electrolysis was also the most useful method to transform organic compounds into more oxygenated ones.

\section{REFERENCES}

Alvares A.B.C., Diaper C. and Parsons S.A. (2001). Partial oxidation by ozone to remove recalcitrance from wastewaters - a review, Environ. Technol., 22, 409-427.

Bijan L. and Mohseni M. (2004). Using ozone to reduce recalcitrant compounds and to enhance biodegradability of pulp and paper effluents, Water Sci. Technol., 50(3), 
173-182.

Bijan L. and Mohseni M. (2005). Integrated ozone and biotreatment of pulp mill effluenct and changes in biodegradability and molecular weight distribution of organic compounds, Water Res., 39, 3763-3772.

Fontanier V., Farines V., Albet J., Baig S. and Molinier J. (2006). Study of catalyzed ozonation for advanced treatment of pulp and paper mill effluents, Water Res., 40 , 303-310.

Gierer J. (1980). Chemical aspects of kraft pulping, Wood Sci. Technol., 14, 241-266.

Glaze W. H. (1986) Reaction products of ozone: a review, Environ. Health Perspect. 69, 151-157.

Glaze W. H., Kang J. and Chapin D. H. (1987). The chemistry of water treatment processes involving ozone, hydrogen peroxide and ultraviolet radiation, Ozone Sci. Eng., 9, 335-352.

Gökcay C. F. and Dilek F. B. (1994). Treatment of effluents from hemp-based pulp and paper industry II. Biological treatability of pulping effluents, Water Sci. Technol., 29(9), 165-168.

Gottschalk C., Libra J. A. and Saupe A. (2000). Ozonation of Water and Waste Water, Wiley-VCH, Weinheim.

Japanese Industrial Standards Committee (1998). Testing methods for industrial wastewater, JIS K 0102, Japanese Standards Association, Tokyo.

Kishimoto N., Morita Y., Tsuno H., Oomura T. and Mizutani H. (2005). Advanced oxidation effect of ozonation combined with electrolysis, Water Res., 39, 4661-4672.

Kishimoto N., Nakagawa T., Asano M., Abe M., Yamada M. and Ono Y. (2008). Ozonation combined with electrolysis of 1,4-dioxane using a two-compartment electrolytic flow cell with solid electrolyte, Water Res., 42, 379-385.

Medeiros D. R., Pires E. C. and Mohseni M. (2008). Ozone oxidation of pulp and paper wastewater and its impact on molecular weight distribution of organic matter, Ozone Sci. Eng., 30, 105-110.

Möbius C. H. and Helble A. (2004). Combined ozonation and biofilm treatment for reuse of paper mill wastewaters, Water Sci. Technol., 49(4), 319-323.

Nakamura Y., Sawada T., Kobayashi F. and Godliving M. (1997). Microbial treatment of kraft pulp wastewater pretreatment with ozone, Water Sci. Technol., 35(2-3), 277-365.

Sevimli M. F. (2005). Post-treatment of pulp and paper industry wastewater by advanced oxidation processes, Ozone Sci. Eng., 27, 37-43.

Standard Methods for the Examination of Water and Wastewater. (1998). 20th edn, American Public Health Association/American Water Works Association/Water Environment Federation, Washington DC, USA.

Tomiyasu H., Fukutomi H. and Gordon G. (1985). Kinetics and mechanism of ozone decomposition in basic aqueous solution, Inorg. Chem., 24, 2962-2966. 